Prepared in cooperation with the Louisiana Department of Transportation and Development

\title{
Water Resources of Vernon Parish
}

\section{Introduction}

In 2005, about 6.67 million gallons per day (Mgal/d) of water were withdrawn in Vernon Parish, Louisiana (fig. 1), including about $6.46 \mathrm{Mgal} / \mathrm{d}$ from groundwater sources and $0.21 \mathrm{Mgal} / \mathrm{d}$ from surface-water sources ${ }^{1}$ (table 1). Publicsupply use accounted for about 76 percent $(5.06 \mathrm{Mgal} / \mathrm{d})$ of the

${ }^{1}$ Tabulation of numbers in text and tables may result in different totals because of rounding; nonrounded numbers are used for calculation of totals. total water withdrawn. Other categories of use included rural domestic, livestock, general irrigation, and aquaculture (table 2). Based on water-use data collected at 5-year intervals from 1960 to 2005, water withdrawals in the parish peaked in 1990 at about $10.4 \mathrm{Mgal} / \mathrm{d}$ (fig. 2).

This fact sheet summarizes basic information on the water resources of Vernon Parish, La. Information on groundwater and surface-water availability, quality, development, use, and trends is based on previously published reports listed in the Selected References section.

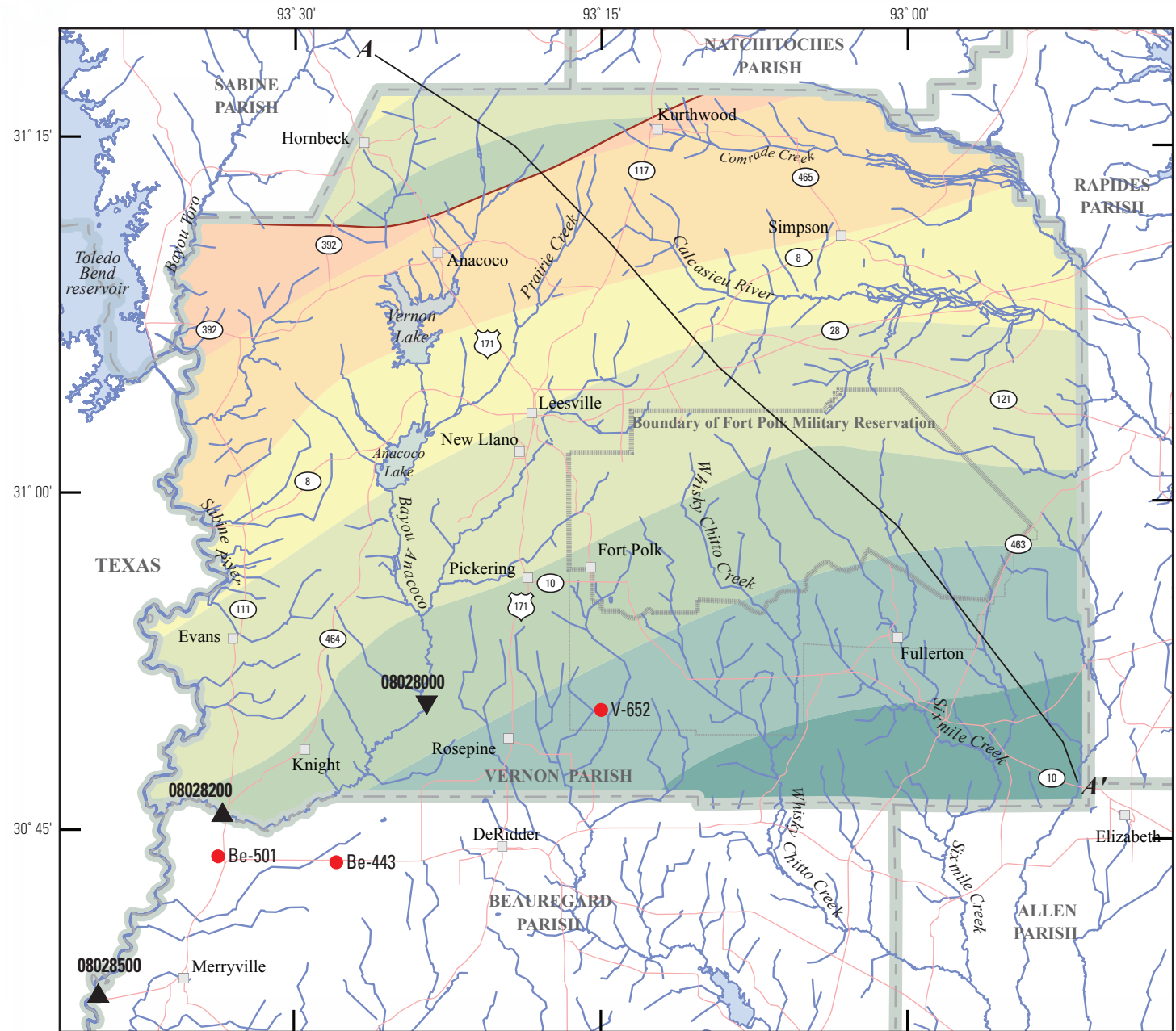

Base map modified from Louisiana Department of Transportation and Development (1986)

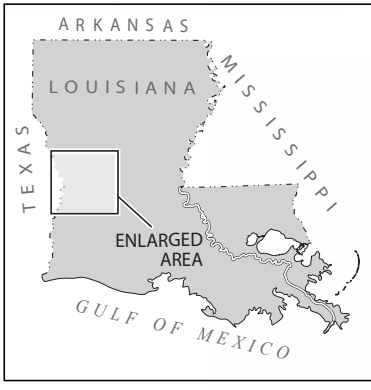

\section{EXPLANATION}

Approximate altitude of base of fresh groundwater, in feet below National Geodetic Vertical Datum of 1929 (NGVD 29) (Smoot, 1988)-Deepest freshwater contained within Catahoula and Carnahan Bayou aquifers, except where noted in the northwestern part of the parish

$\square$ to 499

500 to 999

$\square 1,000$ to 1,499

1,500 to 1,999

2,000 to 2,499

2,500 to 2,999

3,000 and deepe Some intermediate sands can contain saltwater

\begin{tabular}{cc}
\hline & $\begin{array}{c}\text { Boundary of area showing deepest } \\
\text { freshwater contained within } \\
\text { underlying Cockfield aquifer }\end{array}$ \\
$A^{\prime}$ & $\begin{array}{c}\text { Trace of hydrogeologic } \\
\text { section (see fig. 3) } \\
\text { Well for which hydrograph } \\
\text { is shown (see fig. 4) } \\
\text { V-652 }\end{array}$ \\
Surface-water quality site \\
Surface-water discharge site
\end{tabular}

Figure 1. Location of study area, Vernon Parish, Louisiana. 
Table 1. Water withdrawals, in million gallons per day, by source in Vernon Parish, Louisiana, 2005 (modified from Sargent, 2007).

\begin{tabular}{lcc}
\hline $\begin{array}{c}\text { Aquifer, aquifer system, or } \\
\text { surface-water body }\end{array}$ & Groundwater & Surface water \\
\hline Upland terrace aquifer & 0.09 & .55 \\
Chicot aquifer system & .05 & \\
Castor Creek confining unit & .13 & \\
Evangeline aquifer & 5.49 \\
Jasper aquifer system & .12 \\
Catahoula aquifer & .04 & .21 \\
Cockfield aquifer & \\
Miscellaneous streams & 6.46 \\
Total &
\end{tabular}

Table 2. Water withdrawals, in million gallons per day, by category in Vernon Parish, Louisiana, 2005 (modified from Sargent, 2007).

\begin{tabular}{lrrr}
\hline \multicolumn{1}{c}{ Category } & Groundwater & $\begin{array}{c}\text { Surface } \\
\text { Water }\end{array}$ & \multicolumn{1}{c}{ Total } \\
\hline Public-supply & 5.06 & 0.00 & 5.06 \\
Rural domestic & 1.35 & .00 & 1.35 \\
Livestock & .02 & .15 & .16 \\
General irrigation & .00 & .06 & .06 \\
Aquaculture & .03 & .00 & .03 \\
Total & 6.46 & .21 & 6.67 \\
\hline
\end{tabular}

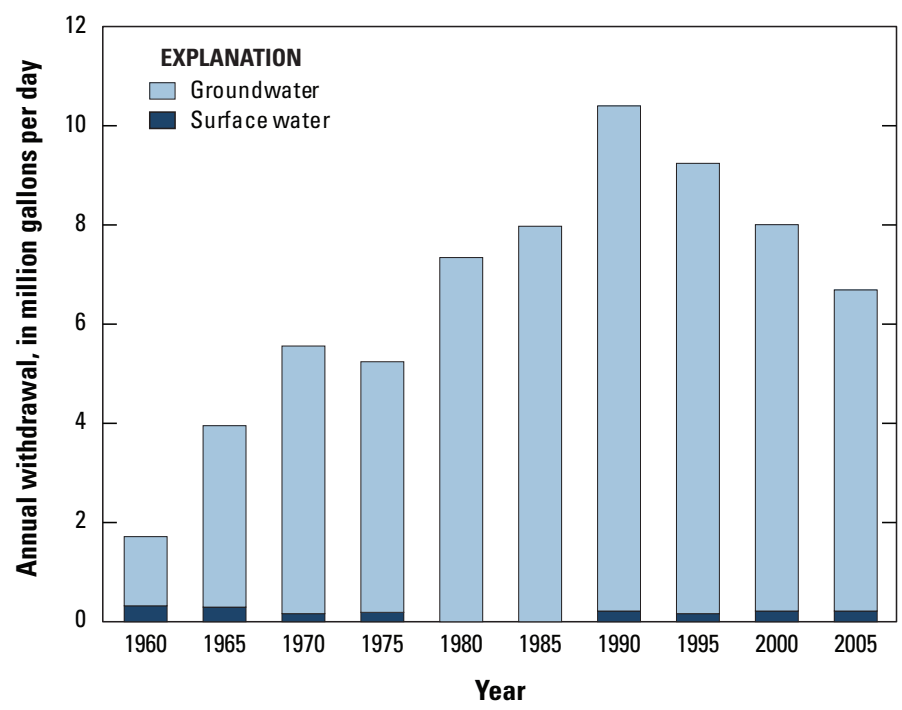

Figure 2. Water withdrawals in Vernon Parish, Louisiana, 1960-2005.

\section{Groundwater Resources}

The primary groundwater resources of Vernon Parish are, from near surface to deepest, the Chicot aquifer system, Evangeline aquifer, and Jasper aquifer system (fig. 3). Secondary groundwater resources in the parish include the upland terrace aquifer, Castor Creek confining unit, Dough Hills confining unit, and the Catahoula and Cockfield aquifers. Although these secondary sources could be important locally, they are not discussed herein. Deeper aquifers in the parish contain only saltwater (water with chloride concentrations greater than 250 milligrams per liter [mg/L]) and are not discussed.

The depth to the base of fresh groundwater varies in Vernon Parish. In the northwestern part of the parish, it ranges in depth from less than 500 to about 2,500 feet (ft) below the National Geodetic Vertical Datum of 1929 (NGVD 29) (sea level). In northeastern areas of the parish, the base of fresh groundwater ranges in depth from about 500 to $1,500 \mathrm{ft}$ below NGVD 29. In the southern part of the parish, the base of freshwater ranges in depth from about 1,500 to more than 3,000 ft below NGVD 29 (fig. 1).

Recharge to the aquifers in Vernon Parish typically is from infiltration of precipitation in outcrop areas, seasonal inflow from streams, and leakage from overlying aquifers. Discharge from the aquifers is by seasonal outflow to streams, leakage into underlying aquifers, and withdrawals from wells.

State well-registration records listed 2,190 active water wells in Vernon Parish in 2009. In 2005, various uses for groundwater withdrawals included public-supply, rural domestic, livestock, and aquaculture (table 2).

\section{Chicot Aquifer System}

The Chicot aquifer system is present in the southern part of Vernon Parish, approximately south of a line extending through the towns of Evans and Fullerton. The aquifer system mostly consists of sand and gravel that is often exposed (outcrops) at land surface. Thickness of the system increases towards the south and is about $200 \mathrm{ft}$ thick near the Vernon-Beauregard Parish line.

Water levels in the outcrop area of the Chicot aquifer system generally fluctuate $1-2 \mathrm{ft}$ annually, as shown in the hydrograph of well Be-443 (fig. 4), which is located west of DeRidder in northern Beauregard Parish (fig. 1). During the 10-year period 1996-2005, water levels at well Be-443 declined at an average rate of 0.14 feet (ft) per year.

State well-registration records listed 524 active wells screened in the Chicot aquifer system in Vernon Parish in 2009. Depths of these wells ranged from 9 to $190 \mathrm{ft}$ below land surface with a median depth of $105 \mathrm{ft}$. Yields from wells screened in the Chicot aquifer system in Vernon Parish reportedly range from 8 to 800 gallons per minute (gal $/ \mathrm{min})$. In 2005, water withdrawals from the Chicot aquifer system in Vernon Parish totaled about $0.55 \mathrm{Mgal} / \mathrm{d}$ and included about $0.14 \mathrm{Mgal} / \mathrm{d}$ for public supply, $0.40 \mathrm{Mgal} / \mathrm{d}$ for rural domestic use, $0.01 \mathrm{Mgal} / \mathrm{d}$ for livestock.

\section{Evangeline Aquifer}

The Evangeline aquifer is present in the southern one-third to one-half of Vernon Parish (fig. 3). The Evangeline aquifer outcrops or subcrops in Vernon Parish from near Pickering, eastward through the southern half of the Fort Polk Military Reservation; the base of the aquifer reaches a maximum depth of about 1,000 ft below 


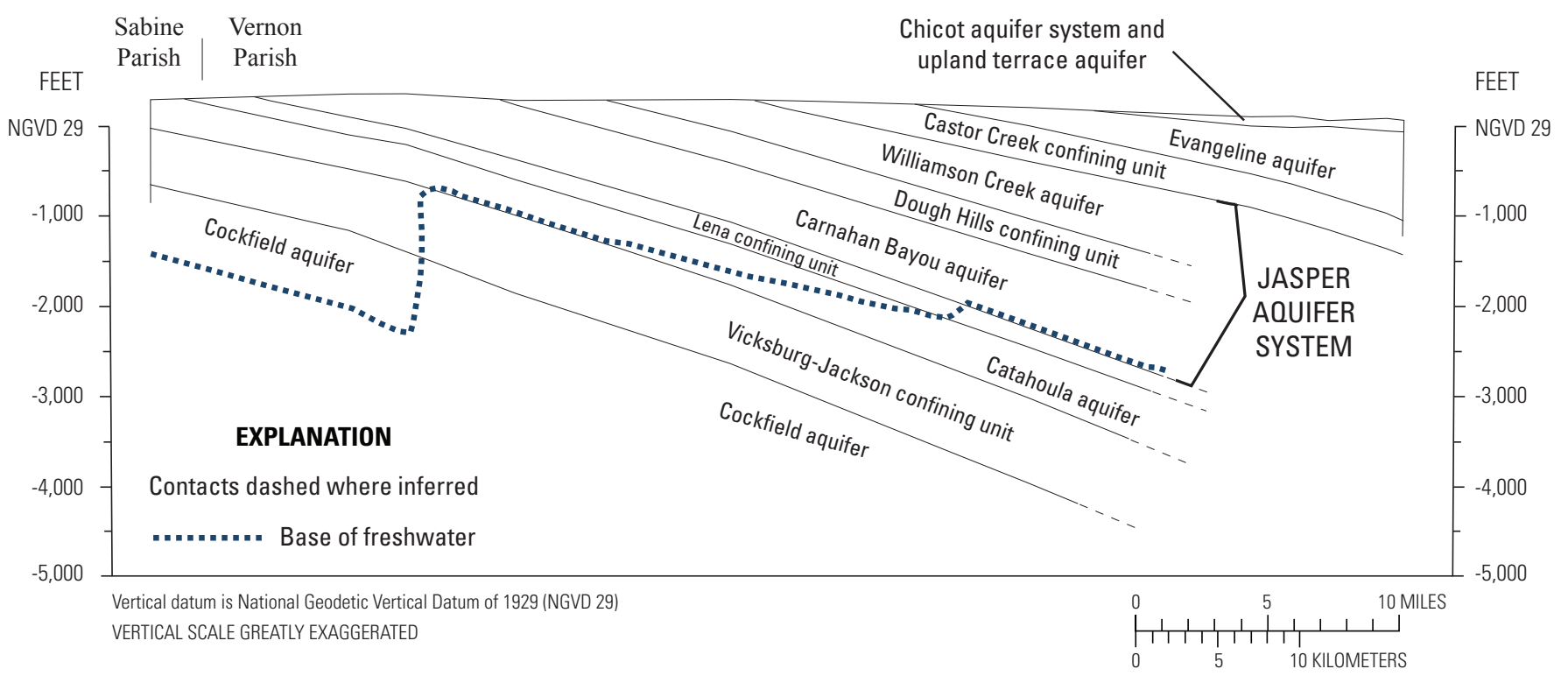

Figure 3. Generalized northwest to southeast geologic section through Vernon Parish, Louisiana (modified from Rogers and Calandro, 1965). Trace of section shown on figure 1.

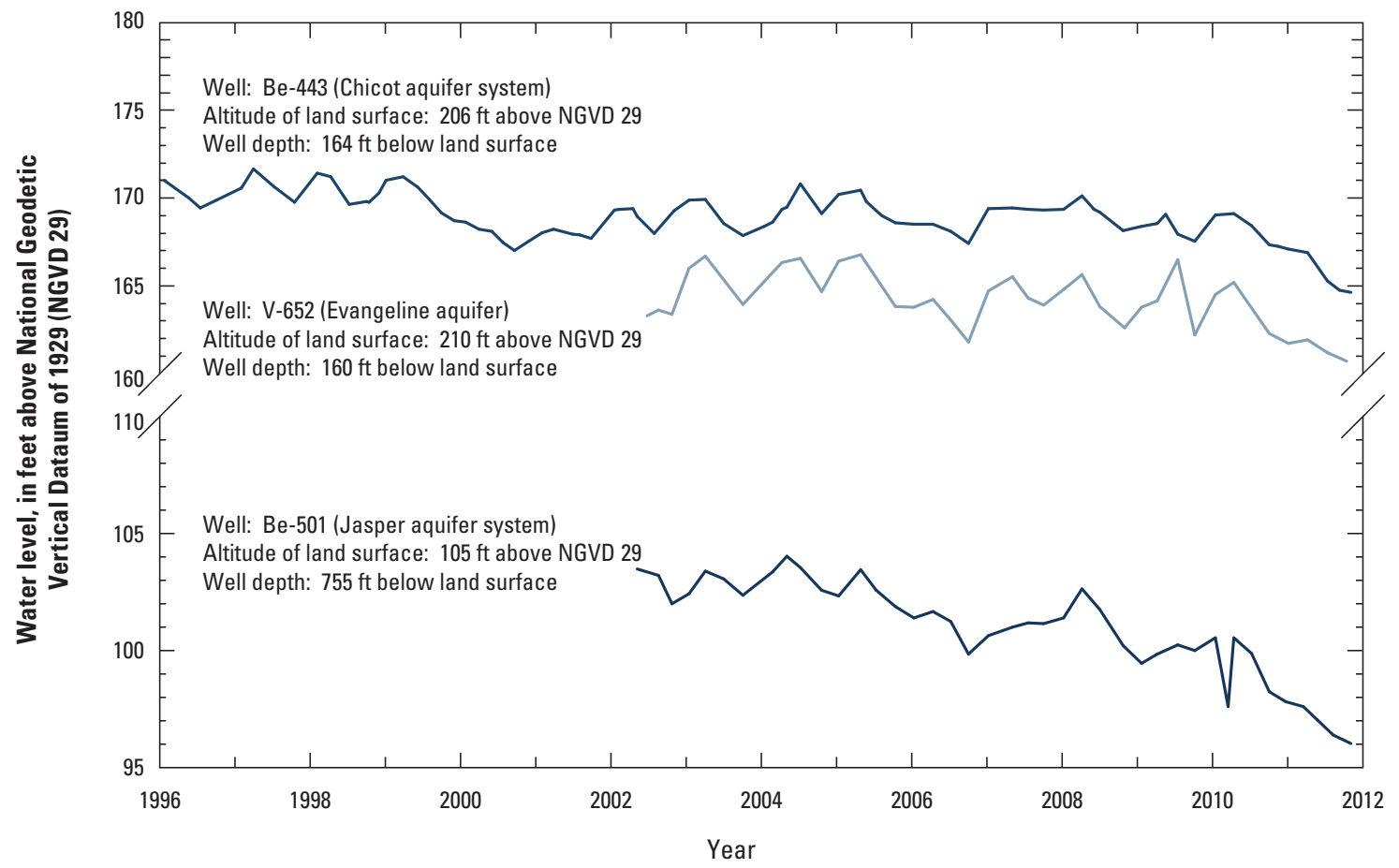

Figure 4. Water levels in well Be-443 screened in the Chicot aquifer system, well V-652 screened in the Evangeline aquifer, and well Be-501 screened in the Jasper aquifer system (see fig. 1 for well locations; U.S. Geological Survey, 2012a). Land surface is measured in feet above the National Geodetic Vertical Datum of 1929 (NGVD 29).

NGVD 29 and a maximum thickness of about 1,100 ft in the southeastern corner of the parish. The aquifer consists primarily of fine to medium sand interbedded with silt, clay, and coarse sand. Locally, sand beds within the aquifer are separated and confined by fairly extensive clays. Sand beds, many thicker than $80 \mathrm{ft}$, make up 35 to 45 percent of the aquifer in Vernon Parish.

In 2004, water levels in the aquifer ranged from about $260 \mathrm{ft}$ above NGVD 29 in the outcrop area of east-central Vernon Parish to about $120 \mathrm{ft}$ above NGVD 29 in the southeastern corner of the parish and $100 \mathrm{ft}$ above NGVD 29 in the southwestern corner of the parish. Water levels generally fluctuate $2-3 \mathrm{ft}$ annually, as shown in the hydrograph of well V-652 (fig. 4), located in south-central Vernon Parish, east-northeast of Rosepine (fig. 1).
State well-registration records listed 90 active wells screened in the Evangeline aquifer in Vernon Parish in 2009. Depths of these wells ranged from 35 to $840 \mathrm{ft}$ below land surface with a median well depth of $208 \mathrm{ft}$. Yields from wells screened in the Evangeline aquifer in Vernon Parish reportedly range from 1 to $230 \mathrm{gal} / \mathrm{min}$. In 2005, withdrawals from the Evangeline aquifer in Vernon Parish totaled about $0.13 \mathrm{Mgal} / \mathrm{d}$.

\section{Jasper Aquifer System}

The Jasper aquifer system consists of the Williamson Creek aquifer, Dough Hills confining unit, and Carnahan Bayou aquifer (fig. 3). Fresh water is present throughout the aquifer system in Vernon Parish, except possibly in the southeastern corner of the 
parish, where saltwater could be present (fig. 1). The Williamson Creek and Carnahan Bayou aquifers consist of well sorted, light gray, very fine to medium sands with occasional traces of gravel and may be interbedded with clay and lignite.

The Williamson Creek aquifer underlies the southern two-thirds of the parish and outcrops diagonally across the parish in a 2-6 mile wide north-south band from the west-central parish line about 5 miles north of Evans, through Leesville, and towards the northeastern corner of the parish. The thickness of the aquifer ranges from $400 \mathrm{ft}$ near the outcrop area to $900 \mathrm{ft}$ in southeastern Vernon Parish. The base of the aquifer is about 2,200 ft below NGVD 29 in the southeastern part of the parish. Sand beds make up about 40 to 60 percent of the aquifer. In 2003, water levels in the aquifer generally ranged from about $200 \mathrm{ft}$ above NGVD 29 in the outcrop area to about $80 \mathrm{ft}$ above NGVD 29 near the town of Rosepine and were less than $60 \mathrm{ft}$ above NGVD 29 in the southeastern corner of the parish. Water levels in well Be-501, screened in the Jasper aquifer system and located in northwestern Beauregard Parish (fig. 1), generally fluctuate 1-3 ft annually and declined by about $7 \mathrm{ft}$ from 2004 to 2011 (fig. 4).

State well-registration records listed 384 active wells screened in the Williamson Creek aquifer in Vernon Parish in 2009. Depths of these wells ranged from 30 to $1,282 \mathrm{ft}$ below land surface with a median well depth of $160 \mathrm{ft}$. Yields from wells screened in the Williamson Creek aquifer in Vernon Parish reportedly range from 4 to $900 \mathrm{gal} / \mathrm{min}$. In 2005, withdrawals from the Williamson Creek aquifer in Vernon Parish were about 2.19 Mgal/d and included about
1.91 Mgal/d for public-supply, $0.26 \mathrm{Mgal} / \mathrm{d}$ for rural domestic use, and $0.02 \mathrm{Mgal} / \mathrm{d}$ for aquaculture.

A statistical summary of selected water-quality characteristics for samples collected from 81 wells screened in the Williamson Creek aquifer is listed in table 3 . Freshwater in the aquifer is generally soft (60 mg/L or less as calcium carbonate) and does not exceed the U.S. Environmental Protection Agency's Secondary Maximum Contaminant Levels (SMCLs) ${ }^{2}$ for drinking water included in table 3. Locally, pH may be less than 6.5 and iron and manganese concentrations may exceed their SMCLs.

The Carnahan Bayou aquifer outcrops in northern and northwestern Vernon Parish in a zone about 8 to 11 miles wide, extending northward and southwestward from a few miles south of the town of Anacoco and northeastward from a few miles south of the town of Kurthwood. The aquifer underlies the central and southern parts of the parish. The thickness of the aquifer ranges from about $540 \mathrm{ft}$ near the outcrop to about $1,100 \mathrm{ft}$ in southeastern Vernon Parish. The base of the aquifer is about 3,600 ft below NGVD 29 in the southeastern part of the parish. Sand beds make up about 25 percent of the unit. Some sand beds have a thickness of $70 \mathrm{ft}$ or more, but most are thinner. In 2003 , water levels in the aquifer generally ranged from about

\footnotetext{
${ }^{2}$ The SMCLs are nonenforceable Federal guidelines regarding cosmetic effects (such as tooth or skin discoloration) or aesthetic effects (such as taste, odor, or color) of drinking water. At high concentrations or values, health implications as well as aesthetic degradation might exist. SMCLs were established as guidelines for the States by the U.S. Environmental Protection Agency (1992).
}

Table 3. Summary of selected water-quality characteristics of freshwater in the Williamson Creek and Carnahan Bayou aquifers in Vernon Parish, Louisiana (U.S. Geological Survey, 2012b).

[Values are in milligrams per liter, except as noted. ${ }^{\circ} \mathrm{C}$, degrees Celsius; PCU, platinum cobalt units; $\mu \mathrm{S} / \mathrm{cm}$, microsiemens per centimeter; $\mathrm{SU}$, standard units; $\mathrm{CaCO}_{3}$, calcium carbonate; $\mu \mathrm{g} / \mathrm{L}$, micrograms per liter; $<$, less than; NA, not applicable; SMCL, Secondary Maximum Contaminant Level established by the U.S. Environmental Protection Agency (2011)]

\begin{tabular}{|c|c|c|c|c|c|c|}
\hline $\begin{array}{l}\text { Temper- } \\
\text { ature }\left({ }^{\circ} \mathrm{C}\right)\end{array}$ & $\begin{array}{l}\text { Color, } \\
\text { (PCU) }\end{array}$ & $\begin{array}{c}\text { Specific } \\
\text { conduc- } \\
\text { tance, field } \\
(\mu \mathrm{S} / \mathrm{cm} \text { at } \\
\left.25^{\circ} \mathrm{C}\right)\end{array}$ & $\begin{array}{l}\mathrm{pH}, \\
\text { field } \\
\text { (SU) }\end{array}$ & $\begin{array}{c}\text { Hardness } \\
\text { (as } \\
\mathrm{CaCO}_{3} \text { ) }\end{array}$ & $\begin{array}{c}\text { Chloride, } \\
\text { filtered } \\
\text { (as CI) }\end{array}$ & $\begin{array}{c}\text { Iron, } \\
\text { filtered } \\
\text { ( } \mu \mathrm{g} / \mathrm{L} \\
\text { as } \mathrm{Fe})\end{array}$ \\
\hline
\end{tabular}

\begin{tabular}{|c|c|c|c|c|c|c|c|c|c|}
\hline \multicolumn{10}{|c|}{ Williamson Creek aquifer (1939-97) (81 wells) } \\
\hline Median & 23.5 & 5 & 253 & 6.8 & 52 & 16 & 100 & 30 & 206 \\
\hline 10th percentile & 21.0 & 0 & 94 & 6.0 & 19 & 8.0 & 10 & 14 & 110 \\
\hline Number of samples & 35 & 28 & 37 & 47 & 81 & 81 & 21 & 16 & 37 \\
\hline $\begin{array}{l}\text { Percentage of samples } \\
\text { that do not exceed } \\
\text { SMCLs }\end{array}$ & NA & 93 & NA & 72 & NA & 100 & 71 & 62 & 97 \\
\hline
\end{tabular}

\begin{tabular}{|c|c|c|c|c|c|c|c|c|c|}
\hline \multicolumn{10}{|c|}{ Carnahan Bayou aquifer (1942-97) (68 wells) } \\
\hline 10th percentile & 21.0 & 2 & 168 & 6.3 & 13 & 9.4 & 12 & $<10$ & 177 \\
\hline Number of samples & 20 & 25 & 31 & 27 & 68 & 67 & 20 & 15 & 31 \\
\hline $\begin{array}{l}\text { Percentage of samples } \\
\text { that do not exceed } \\
\text { SMCLs }\end{array}$ & NA & 84 & NA & 85 & NA & 100 & 80 & 47 & 100 \\
\hline
\end{tabular}

\begin{tabular}{llllllllll}
\hline \multicolumn{10}{c}{ SMCLs } \\
\hline NA & 15 & NA & $6.5-8.5$ & NA & 250 & 300 & 50 & 500 \\
\hline
\end{tabular}


$300 \mathrm{ft}$ above NGVD 29 in the outcrop area in north-central Vernon Parish to about $100 \mathrm{ft}$ above NGVD 29 in east-central Vernon Parish near the border with Rapides Parish.

State well-registration records listed 590 active water wells screened in the Carnahan Bayou aquifer in Vernon Parish in 2009. Depths of these wells ranged from 25 to $1,574 \mathrm{ft}$ below land surface with a median depth of $140 \mathrm{ft}$. Yields from wells screened in the aquifer in Vernon Parish reportedly range from 3 to 1,500 gal $/ \mathrm{min}$. In 2005, withdrawals from the Carnahan Bayou aquifer in Vernon Parish were about $3.19 \mathrm{Mgal} / \mathrm{d}$, and included about $2.80 \mathrm{Mgal} / \mathrm{d}$ for public-supply and $0.39 \mathrm{Mgal} / \mathrm{d}$ for rural domestic use.

A statistical summary of selected water-quality characteristics for freshwater samples collected from 68 wells screened in the Carnahan Bayou aquifer is provided in table 3. Freshwater in the aquifer system is generally moderately hard $(61-120 \mathrm{mg} / \mathrm{L}$ as calcium carbonate) and, with the exception of manganese, generally does not exceed SMCLs for drinking water included in table 3.

\section{Surface-Water Resources}

In 2005 , about $0.21 \mathrm{Mgal} / \mathrm{d}$ of surface water was withdrawn in Vernon Parish, including about $0.15 \mathrm{Mgal} / \mathrm{d}$ for livestock and $0.06 \mathrm{Mgal} / \mathrm{d}$ for general irrigation (table 2). Major streams in the parish include the Sabine River, Bayou Anacoco, Calcasieu River, Sixmile Creek, and Whisky Chitto Creek. Anacoco Lake and Vernon Lake are engineered reservoirs located on Bayou Anacoco (fig. 1).

Some streams in the southern and western parts of the parish, such as the Sabine River, Bayou Anacoco, and Whisky Chitto Creek (fig. 1), are underlain by permeable soils or sediments that have a large capacity for surface-water and groundwater interaction, and streamflow in these basins is sustained by base flow during dry periods. Streams in the northeastern part of the parish, such as the Calcasieu River and Comrade Creek, are underlain by relatively impermeable rocks or poorly drained subsoils. Streamflows in these areas recede rapidly from flood peaks to rates of low flow or even to no flow.

The mean discharge for the Sabine River near Bon Wier (station number 08028500), Texas (fig. 1), from 1961-2009, was 6,680 cubic feet per second $\left(\mathrm{ft}^{3} / \mathrm{sec}\right.$ ) (U.S. Geological Survey, 2009). The drainage area of the Sabine River at this site, located about 9 miles south of Vernon Parish on U.S. Highway 190 west of Merryville, La., is about 8,230 square miles $\left(\mathrm{mi}^{2}\right)$. Water samples from this site, analyzed during the period 1969-2009 indicate that water in the Sabine River (fig. 1) is generally soft (table 4) and generally does not exceed SMCLs for drinking water included in table 3. Dissolved oxygen is generally greater than $5 \mathrm{mg} / \mathrm{L}$, which is considered the minimum value for a diversified population of fresh,

Table 4. Summary of selected water-quality characteristics for the Sabine River near Bon Wier, Texas, and Bayou Anacoco near Knight, Louisiana.

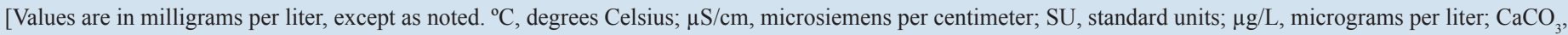
calcium carbonate; - , no data; NA, not applicable; SMCL, Secondary Maximum Contaminant Level established by the U.S. Environmental Protection Agency (2011)]

\begin{tabular}{|c|c|c|c|c|c|c|c|c|c|c|c|}
\hline & $\begin{array}{c}\text { Specific } \\
\text { conduc- } \\
\text { tance, } \\
\text { field } \\
\text { ( } \mathrm{HS} / \mathrm{cm} \\
\text { at } 25^{\circ} \mathrm{C} \text { ) }\end{array}$ & $\begin{array}{l}\text { Oxygen, } \\
\text { dis- } \\
\text { solved }\end{array}$ & $\begin{array}{l}\text { pH, } \\
\text { field } \\
\text { (SU) }\end{array}$ & $\begin{array}{c}\text { Hard- } \\
\text { ness } \\
\text { (as } \\
\mathrm{CaCO}_{3} \text { ) }\end{array}$ & $\begin{array}{l}\text { Calcium, } \\
\text { filtered } \\
\text { (as Ca) }\end{array}$ & $\begin{array}{l}\text { Mag- } \\
\text { nesium, } \\
\text { filtered } \\
\text { (as Mg) }\end{array}$ & $\begin{array}{l}\text { Sodium, } \\
\text { filtered } \\
\text { (as Na) }\end{array}$ & $\begin{array}{l}\text { Chlor- } \\
\text { ide, } \\
\text { filtered } \\
\text { (as CI) }\end{array}$ & $\begin{array}{l}\text { Sulfate, } \\
\text { filtered } \\
\text { (as } \mathrm{SO}_{4} \text { ) }\end{array}$ & $\begin{array}{c}\text { Iron, non- } \\
\text { filtered } \\
\text { ( } \mu \mathrm{g} / \mathrm{L} \\
\text { as Fe) }\end{array}$ & $\begin{array}{c}\text { Iron, } \\
\text { fil- } \\
\text { tered } \\
\text { ( } \mu \mathrm{g} / \mathrm{L} \\
\text { as Fe) }\end{array}$ \\
\hline \multicolumn{12}{|c|}{ Sabine River near Bon Wier, Tex., 1969-2009¹ } \\
\hline Median & 153 & 8.4 & 7.2 & 38 & 9.7 & 2.7 & 22 & 17 & 18 & 50 & - \\
\hline 10th percentile & 112 & 6.7 & 6.6 & 26 & 7.4 & 1.6 & 12 & 12 & 11 & 20 & - \\
\hline 90th percentile & 213 & 9.9 & 7.5 & 46 & 13 & 3.9 & 30 & 27 & 28 & 160 & - \\
\hline Number of samples & 1,696 & 37 & 57 & 33 & 33 & 33 & 33 & 1,684 & 1,684 & 30 & - \\
\hline $\begin{array}{l}\text { Percentage of } \\
\text { samples that do } \\
\text { not exceed SMCLs }\end{array}$ & NA & NA & 96 & NA & NA & NA & NA & 100 & 100 & 93 & - \\
\hline \multicolumn{12}{|c|}{ Bayou Anacoco near Knight, La., 1969-2009² } \\
\hline Median & 310 & 7.6 & 7.0 & 25 & 8.1 & 1.2 & 52 & 21 & 56 & - & 250 \\
\hline 10th percentile & 76 & 6.0 & 6.4 & 13 & 4.1 & 0.6 & 9.2 & 5.9 & 10 & - & 140 \\
\hline 90th percentile & 676 & 9.8 & 7.5 & 43 & 15 & 2.0 & 120 & 58 & 150 & - & 410 \\
\hline Number of samples & 206 & 195 & 209 & 200 & 200 & 200 & 200 & 206 & 205 & - & 90 \\
\hline $\begin{array}{l}\text { Percentage of } \\
\text { samples that do } \\
\text { not exceed SMCLs }\end{array}$ & NA & NA & 88 & NA & NA & NA & NA & 100 & 100 & - & 70 \\
\hline \multicolumn{12}{|c|}{ SMCLs } \\
\hline & NA & NA & $6.5-8.5$ & NA & NA & NA & NA & 250 & 250 & 300 & 300 \\
\hline
\end{tabular}


warm-water biota, including sport fish (Louisiana Department of Environmental Quality, 2008).

The mean discharge for Bayou Anacoco near Rosepine, La. (fig. 1) from 1952-2008 was $483 \mathrm{ft}^{3} / \mathrm{sec}$ (station number 08028000). The drainage area at this site is about $365 \mathrm{mi}^{2}$ (U.S. Geological Survey, 2008). Water samples from Bayou Anacoco near Knight, La. (station number 08028200) (fig. 1) that were analyzed during the period 1969-2009 indicate that the water is soft (table 4) and generally does not exceed SMCLs for drinking water included in table 3 . Dissolved oxygen is generally greater than $5 \mathrm{mg} / \mathrm{L}$.

\section{Selected References}

Louisiana Department of Environmental Quality, 2008, Environmental Regulatory Code, Title 33, Part IX, Subpart 1, accessed June 9, 2009, at http:www.deq.louisiana.gov/ portal/tabid/1674/Default.aspx.

Louisiana Department of Transportation and Development, 1986, Official map of Louisiana - 1986 edition: Baton Rouge, Louisiana Department of Transportation and Development, 1 sheet.

Rogers, J.E., and Calandro, A.J., 1965, Water resources of Vernon Parish, Louisiana: Department of Conservation, Louisiana Geological Survey, and Louisiana Department of Public Works Water Resources Bulletin no. 6, 104 p.

Sargent, B.P., 2007, Water use in Louisiana, 2005: Louisiana Department of Transportation and Development Water Resources Special Report no. 16, 133 p.

Smoot, C.W., 1988, Louisiana hydrologic atlas map no. 3-Altitude of the base of freshwater in Louisiana: U.S. Geological Survey Water-Resources Investigations Report 86-4314, 1 sheet, accessed November 29, 2011, at http://pubs. usgs.gov/wri/1986/4314/plate-1.pdf.

U.S. Environmental Protection Agency, 1992, Secondary Drinking Water Regulations_-Guidance for nuisance chemicals: U.S. Environmental Protection Agency publication EPA 810/K-92-001, 4 p., accessed September 28, 2011, at http:// water.epa.gov/drink/contaminants/secondarystandards.cfm.

U.S. Environmental Protection Agency, 2011, 2011 Edition of the drinking water standards and health advisories: U.S. Environmental Protection Agency publication EPA 820-R11-002, Office of Water, 12 p., accessed September 2, 2011, at http://water.epa.gov/action/advisories/drinking/upload/ dwstandards2011.pdf.

U.S. Geological Survey, 2008, Water-data report 2008 [for gage 08028000 Bayou Anacoco near Rosepine, LA]: U.S. Geological Survey Water Resources of the United States, accessed May 1, 2009, at http://wdr.water.usgs.gov/wy2008/ pdfs/08028000.2008.pdf.
U.S. Geological Survey, 2009, Annual water-data report 2009 [for gage 08028500 Sabine River near Bon Wier, TX]: U.S. Geological Survey Water Resources of the United States, accessed January 7, 2011, at http://wdr.water.usgs.gov/wy2009/ pdfs/08028500.2009.pdf.

U.S. Geological Survey, 2009b, Water Quality Samples for Louisiana [data for USGS 08028200 Bayou Anacoco near Knight, LA.]: National Water Information System Web Interface, accessed February 3, 2010, at http://nwis.waterdata. usgs.gov/la/nwis/qwdata/?site_no $=08028200$.

U.S. Geological Survey, 2012a, Ground-water levels for Louisiana: National Water Information System Web Interface accessed November 18, 2011, at http://nwis.waterdata.usgs.gov/ la/nwis/gwlevels.

U.S. Geological Survey, 2012b, Water quality samples for Louisiana: National Water Information System Web Interface, accessed February 3, 2010, at http://nwis.waterdata.usgs.gov/ la/nwis/qwdata/.

U.S. Geological Survey, 2012c, Water quality samples for Texas: National Water Information System Web Interface, accessed January 7, 2010, at http:// nwis.waterdata.usgs.gov/tx/nwis/ qwdata/.

Whitfield, M.S., Jr., 1975, Geohydrology of the Evangeline and Jasper aquifers of southwestern Louisiana: Department of Conservation, Louisiana Geological Survey, and Louisiana Department of Public Works Water Resources Bulletin no. $20,72 \mathrm{p}$.

\section{By Lawrence B. Prakken , Jason M. Griffith, and Robert B. Fendick, Jr}

\section{For additional information, contact:}

Director, USGS Louisiana Water Science Center 3535 S. Sherwood Forest Blvd., Suite 120

Baton Rouge, LA 70816

E-mail: dc_la@usgs.gov

Fax: (225) 298-5490

Telephone: (225) 298-5481

Home Page: http://la.water.usgs.gov

This fact sheet was published by the U.S. Geological Survey, in cooperation with the Louisiana Department of Transportation and Development (DOTD). Thanks are given to Zahir "Bo" Bolourchi, Director, Water Resources Programs, Louisiana Department of Transportation and Development, who contributed to the content and design of the fact sheet. 